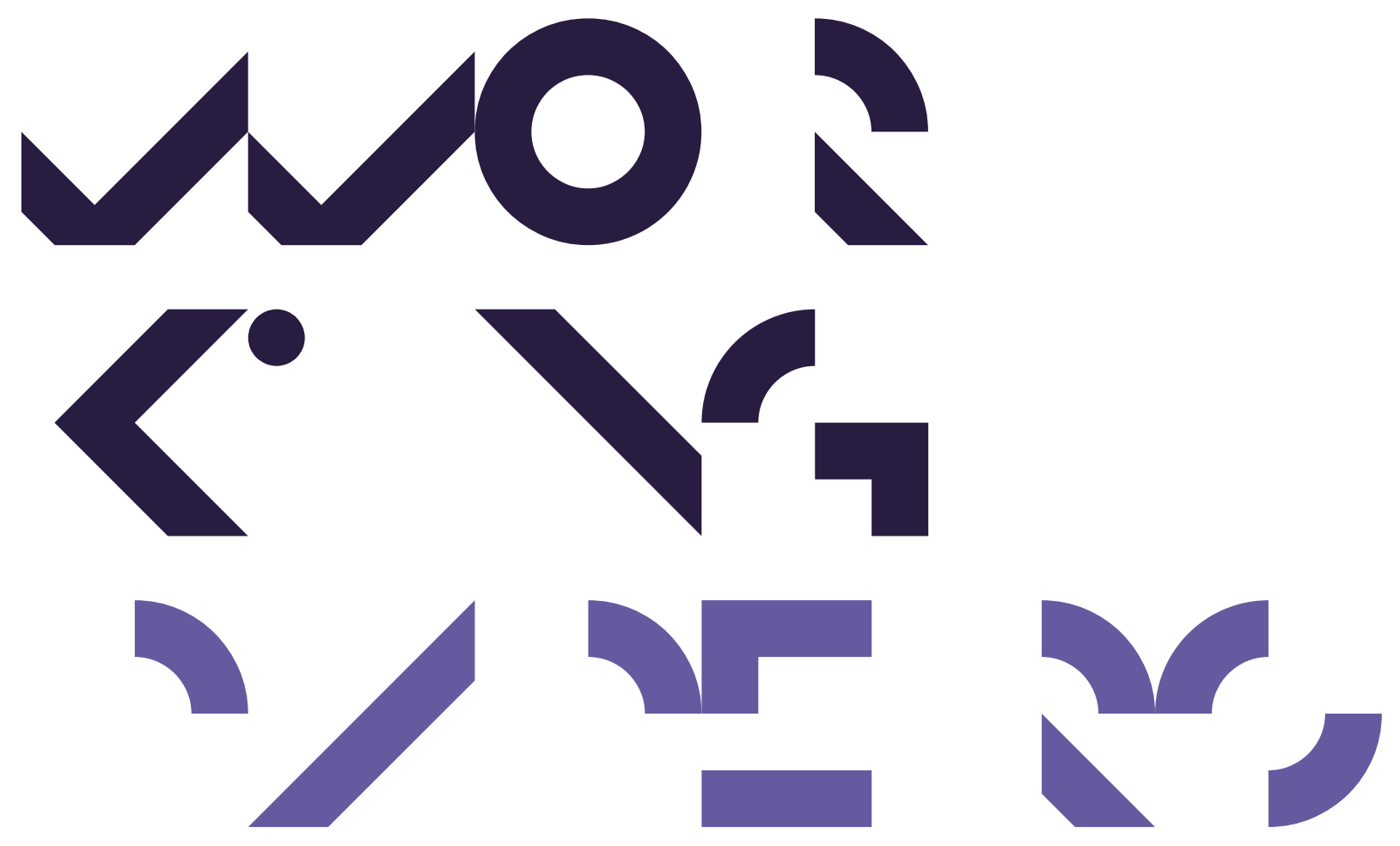

Economics Working Papers

2014-06

Measuring multi-membership in economic integration and its trade-impact. A comparative study of ECOWAS and SADC

Sylvanus Kwaku Afesorgbor and Peter A.G. van Bergeijk Sylvanus Kwaku Afesorgbor and Peter A.G. van Bergeijk 


\title{
Measuring multi-membership in economic integration and its trade-impact. A comparative study of ECOWAS and SADC
}

Sylvanus Kwaku Afesorgbor, PhD Fellow, Aarhus University, Denmark

Peter A.G. van Bergeijk, Professor, the international Institute of Social Studies of Erasmus University, The Hague, Netherlands

\begin{abstract}
One of intriguing aspects of African Regional Trade Agreements (RTAs) is the extent of multi-membership, where many Africa countries are members of more than one RTA. Using a gravity model for 25 countries and the years 1980-2006 we measure the extent of multi-membership and compare its impact in two major African Regional blocs, ECOWAS and SADC. We find that the impact of multi-membership critically depends on the characteristics of the multi-membership of regional integration initiatives. We find a positive impact if an additional membership complements the integration process of the original regional integration initiative: overlapping memberships had a much stronger and significant positive effect on bilateral trade within ECOWAS compare to an insignificant impact within SADC.
\end{abstract}

Keywords: Multi-membership, Regional Economic Integration, Gravity Model, ECOWAS, SADC.

JEL: F1, F15 


\section{Introduction}

Trade by and between Sub-Saharan African Countries is an important and versatile research topic for at least two reasons. Firstly, the potential contribution of regional trade agreements (RTAs) in Africa has been contested both on theoretical and empirical grounds. In a nutshell the arguments are that (a) similarities of comparative advantages and structural supply side characteristics imply that African RTAs will have a smaller contribution to bilateral trade flows compared to North-South RTAs and (b) that the 'spaghetti bowl' of African regional economic integration (REI) schemes mainly creates red tape and inconsistencies that actually hamper intra-regional trade (ECA, 2004, p.41, Chacha, 2013, p. 10). An extensive econometric investigation using a metaanalysis refutes the former argument (a) and shows that some of the RTAs have made some positive gains while others have realised a disappointing performance (Afesorgbor, 2013). However, (b) has not seen much extensive research. This article provides nuance for the latter argument by showing that multi-RTA membership actually strengthens intra-regional trade if the additional membership of other RTAs complements the integration process of the original RTA.

Secondly, economic integration in Africa is interesting from a research point of view, because the continent has a very high density and diversity of REIs. According to Yang and Gustav (2005, p.5), RTAs have been proliferating exponentially and Africa has now a dense web of RTAs. This implies that a lot of variation exists both across countries and across RTAs. The high density and diversity has led to an intriguing multi-membership, where many African countries are members of several different REIs. Out of the total number of 53 African countries, 47 are members of more than one RTA and only 6 maintain single membership of just one RTA (ECA, 2004). This stylized fact offers an intriguing puzzle and illustrates that Africa provides a unique testing ground for alternative theories on the impact of (multiple) RTA membership.

This article contributes to the literature by measuring multi-membership in two major African REIs and comparing how the effect of multi-membership differs in these two regional blocs: the Economic Community of West Africa States (ECOWAS) 
and the Southern Africa Development Community (SADC). ECOWAS consist of 15 West African countries with a combined GDP of US\$396 billion and a total population of 319 million (World Bank Development Indicators, data for 2012). ECOWAS was established by the Treaty of Lagos on 20 th May 1975 by the 15 West Africa states. In 1993, a revised Treaty (Abuja Treaty) was signed with the main aim of accelerating economic integration and promoting cooperation and development of the member states. SADC also consists of 15 countries. Total GDP and population in 2012 were $\$ 648$ billion and 285 million respectively. SADC as regional bloc was formed in the 1992 Windhoek Summit that transformed the Southern African Development Coordination Conference (SADCC) into a more formalised and integrated community (Söderbaum, 1994).

ECOWAS and SADC blocs are at the initial level of integration: a free trade agreement (FTA), where trade barriers on member's export and import are removed but member countries maintain their respective tariffs on goods from nonmember countries. In the case of ECOWAS, member states implemented the first phase of trade liberalization eliminating trade tariff barriers on unprocessed goods and traditional handicraft and some of the countries extending the FTA to industrial goods. Comparatively, SADC's FTA covers both primary and industrial goods. According to ECA (2012) both blocs have achieved the second stage of integration process by coordinating and harmonizing activities and progressively eliminating tariff and non-tariff barriers. ECOWAS and SADC have achieved the goal of free movement of citizens of member states. Entry of citizens from member countries does not require visas for a period of up to 90 days.

Our comparative methodology allows us to elucidate the extent of multimembership in African REIs (ECOWAS and SADC). Since ECOWAS and SADC are two completely different clubs that do not have any overlapping membership, a comparison of these two REIs offers a sound and unambiguous basis for an investigation of the impact of multi REI-membership. Using a gravity model for 25 countries and the years 1980-2006 we estimate the impact of multi-membership and compare how the effect differs for these two regional blocs.

This paper provides a novelty from both the empirical and theoretical perspectives. Empirically, it is the first paper to the best of our knowledge that 
measures and compares the trade impact of overlapping (multi) membership in economic integration using the international trade empirical workhorse, the gravity model. Additionally, in an approach very different from Chacha ${ }^{1}$ (2013), we define multi-membership as a count of RTAs that a country-pair are both members of, in contrast to Chacha that measures multi-membership at the RTA level. Theoretically, we also question the assertion of only looking at multi-membership of RTAs as complication and duplication by also considering the possibility that some of the RTAs can be complementary. The empirical findings support our theoretical reasoning that the impact of multi REI-membership critically depends on the characteristics of the overlapping RTA. In particular we find a positive impact if additional membership complements the integration process of the original REI: overlapping memberships had a significant positive effect on bilateral trade within the ECOWAS bloc but it is insignificant for SADC.

The remainder of this article is organized as follows. Section 1 offers a snapshot of the African REI spaghetti bowl in 2010 and multi-membership in ECOWAS and SADC in particular. Section 2 reviews the theoretical and empirical literature that deals with multi-memberships in RTAs. Section 3 introduces our tool of analysis (the gravity model) and our data set and motivates our methodological choices and empirical operationalization. Section 4 presents and discusses the empirical findings. Section 5 draws conclusions and policy implications.

\section{The spaghetti bowl of African regional integration initiatives}

History shows that regional integration in Africa has been a process of trial and error in negotiations that were often fraught by political difficulties and followed up by renewed efforts (Ezenwe, 1983; Soderbaum, 1996; Herman et al. 2011). As a consequence of the many initiatives and different fortunes of regional integration initiatives, the African landscape is complex to say the least with many REIs and intersecting memberships of the many regional blocs. The rising wave of regionalism on the continent gives credence to Bhagwati and Panagariya (1999)

\footnotetext{
${ }^{1}$ Chacha (2013) is the only study that empirically looked at regional integration and challenge of overlapping membership on trade.
} 
coined term "spaghetti bowl" of RTAs on the world. The Africa version of the crisscrossing RTAs described by Yang and Gupta (2005) as the "African Galaxy" is best delineated in the Figure 1.

\section{Figure 1: Overlapping membership in African REIs (African galaxy)}

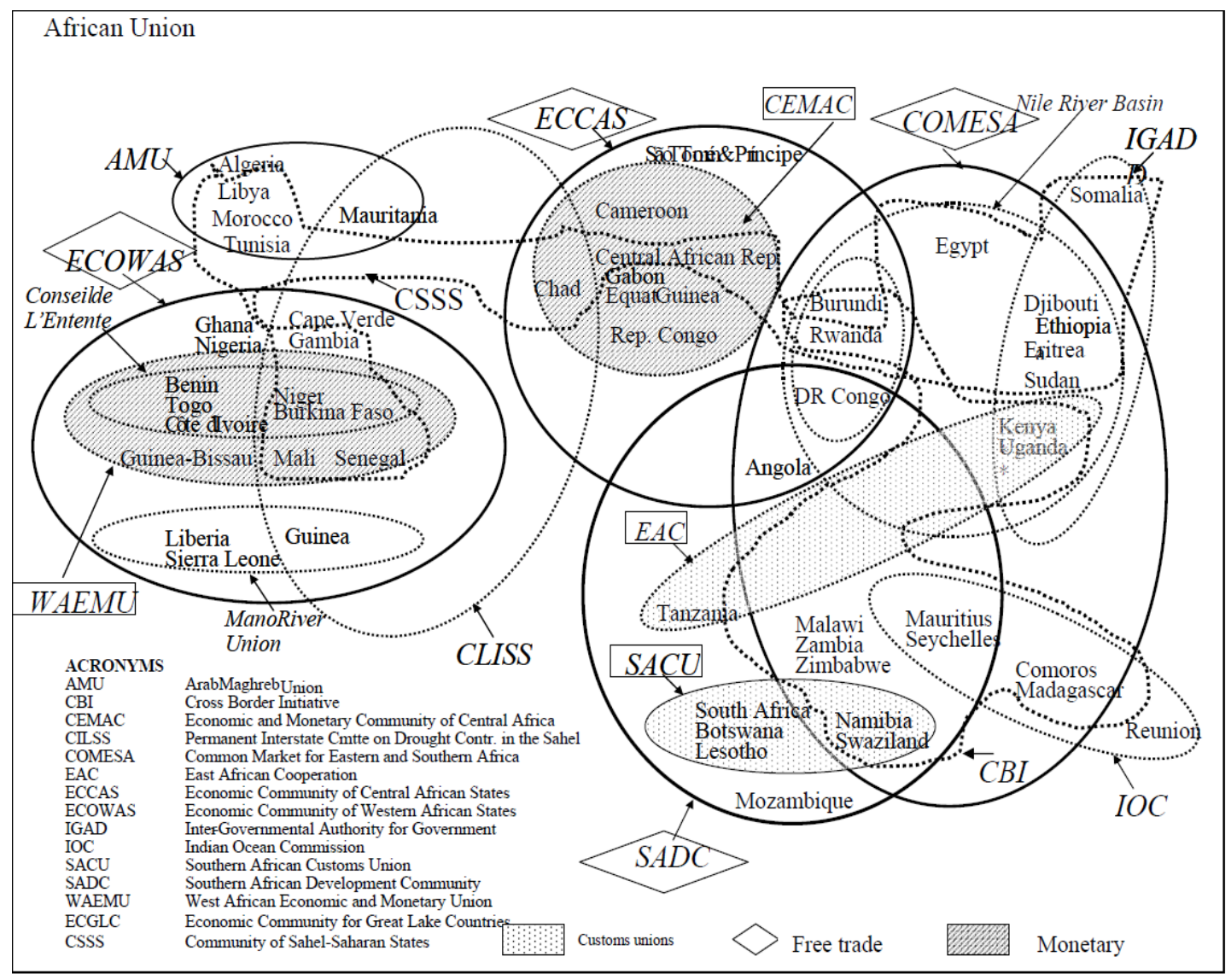

Source: Yang and Gupta (2005, pp.11)

Table 1 provides details on multiple memberships of ECOWAS and SADC member states. West and Southern Africa consist of six different REIs, with each country belonging to at least two of the six REIs. ECOWAS and SADC in 2010 had 15 member states. ECOWAS members: Niger, Guinea and Burkina Faso have the highest multiple memberships, belonging to 4 of the regional groupings; in SADC only DR Congo belongs to 4 RTAs. On average multi-membership occurs more in ECOWAS as each member of ECOWAS belongs to three REIs compare to SADC members that on average belongs to two REIs. The key question that we address in this article is if and how these membership patterns influence bilateral trade. 
TABLE 1: Multiple Memberships of ECOWAS and SADC Members, 2010 (year of establishment in brackets)

\begin{tabular}{|c|c|c|c|c|c|c|}
\hline ECOWAS Members & Number & $\begin{array}{l}\text { West African } \\
\text { Economic and } \\
\text { Monetary } \\
\text { Union-WAEMU } \\
\text { (1975) }\end{array}$ & $\begin{array}{l}\text { West Africa } \\
\text { Monetary } \\
\text { Zone-WAMZ } \\
(2000)\end{array}$ & $\begin{array}{l}\text { Mano } \\
\text { River } \\
\text { Union- } \\
\text { MRU } \\
\text { (1973) }\end{array}$ & $\begin{array}{l}\text { Entente } \\
\text { Council-EC } \\
\text { (1959) }\end{array}$ & $\begin{array}{l}\text { Permanent } \\
\text { CInterstate } \\
\text { Committee } \\
\text { on Drought } \\
\text { Control in } \\
\text { the Sahel - } \\
\text { CILSS (1973) }\end{array}$ \\
\hline Benin & 3 & $\mathrm{X}$ & & & $\mathrm{X}$ & \\
\hline Burkina Faso & 4 & $\mathrm{X}$ & & & $\mathrm{X}$ & $\mathrm{X}$ \\
\hline Cabo Verde & 2 & & & $\mathrm{X}$ & & \\
\hline Côte d'Ivoire & 3 & $\mathrm{X}$ & & & $\mathrm{X}$ & \\
\hline Gambia & 2 & & $X$ & & & \\
\hline Ghana & 2 & & $\mathrm{X}$ & & & \\
\hline Guinea & 4 & & $X$ & $\mathrm{X}$ & & $\mathrm{X}$ \\
\hline Guinea Bissau & 2 & $X$ & & & & \\
\hline Liberia & 3 & & $\mathrm{X}$ & $\mathrm{X}$ & & \\
\hline Mali & 3 & $\mathrm{X}$ & & & & $\mathrm{X}$ \\
\hline Niger & 4 & $\mathrm{X}$ & & & $\mathrm{X}$ & $\mathrm{X}$ \\
\hline Nigeria & 2 & & $X$ & & & \\
\hline Senegal & 3 & $\mathrm{X}$ & & & & $\mathrm{X}$ \\
\hline Sierra Leone & 3 & & $\mathrm{X}$ & $\mathrm{X}$ & & \\
\hline Togo & 3 & $\mathrm{X}$ & & & $\mathrm{X}$ & \\
\hline SADC Members & Number & $\begin{array}{l}\text { Common } \\
\text { Market for } \\
\text { Eastern and } \\
\text { Southern } \\
\text { Africa- } \\
\text { COMESA } \\
\text { (1993) }\end{array}$ & $\begin{array}{l}\text { Economic } \\
\text { Community } \\
\text { of Central } \\
\text { African } \\
\text { States-ECCAS } \\
\text { (1981) }\end{array}$ & $\begin{array}{l}\text { Southe } \\
\text { rn } \\
\text { Africa } \\
\text { Custom } \\
\text { Union- } \\
\text { SACU } \\
(1969)\end{array}$ & $\begin{array}{l}\text { Indian } \\
\text { Ocean } \\
\text { Commis } \\
\text { sion-IOC } \\
(1982)\end{array}$ & $\begin{array}{l}\text { East African } \\
\text { Community - } \\
\text { EAC(1967) }\end{array}$ \\
\hline Angola & 3 & $\mathrm{X}$ & $\mathrm{X}$ & & & \\
\hline Botswana & 3 & & & $\mathrm{X}$ & & $\mathrm{X}$ \\
\hline DR Congo & 4 & $\mathrm{X}$ & $\mathrm{X}$ & & $\mathrm{X}$ & \\
\hline Lesotho & 2 & & & $\mathrm{X}$ & & \\
\hline Madagascar & 2 & $\mathrm{X}$ & & & & \\
\hline Malawi & 3 & $\mathrm{X}$ & & & $\mathrm{X}$ & \\
\hline Mauritius & 2 & $\mathrm{X}$ & & & & \\
\hline Mozambique & 1 & & & & & \\
\hline Namibia & 3 & $\mathrm{X}$ & & $\mathrm{X}$ & & \\
\hline Seychelles & 3 & $\mathrm{X}$ & & & $\mathrm{X}$ & \\
\hline South Africa & 2 & & & $\mathrm{X}$ & & \\
\hline Swaziland & 3 & $\mathrm{X}$ & & $\mathrm{X}$ & & \\
\hline Tanzania & 2 & & & & & $\mathrm{X}$ \\
\hline Zambia & 2 & $\mathrm{X}$ & & & & \\
\hline Zimbabwe & 2 & $\mathrm{X}$ & & & & \\
\hline
\end{tabular}

Source: Authors' computation based on memberships from blocs' websites. 
Table 2 looks at multiple memberships in terms of the number of non-zero bilateral trade flows of country pairs in different membership of RTAs. Multiple membership is defined as the number of REIs to which both the exporter country and importer country belong (the count thus refers to the country-pair or dyads). An interesting noticeable trend from table 2 for ECOWAS countries is that as the number of REIs that a pair of country belongs to increases, the average bilateral trade flow increases. An additional membership to a dyad or country pair in just one REI almost doubles average trade between them, however, excessive' multiple membership (i.e. more than 2 REIs) leads to an increase but with diminishing effect on average bilateral trade. In contrast for SADC countries, a country pair in more than one REI results in diminishing effect on average bilateral trade between them. This simple stylized fact provides underpinnings for the thought that the impact of multi-membership may differ for different regional blocs.

TABLE 2: Single and multi-membership in terms of bilateral trade, average 1980-2006 (Million US\$)

\begin{tabular}{ccc}
\hline $\begin{array}{c}\text { Number of REIs a dyad } \\
\text { belong }\end{array}$ & ECOWAS & SADC \\
\hline $\mathbf{1}$ & 7.79 & 50.37 \\
& $(50.58)$ & $(152.39)$ \\
$\mathbf{2}$ & 15.03 & 8.70 \\
& $(61.09)$ & $(23.87)$ \\
$\mathbf{3}$ & 17.53 & 3.39 \\
& $(34.78)$ & $(5.44)$ \\
\hline
\end{tabular}

Source: Authors' computation based on the DoTs.

\subsection{Overlapping multi-RTA membership}

Generally speaking, multi-membership in RTAs is not a new phenomenon (for example the Benelux - a free trade agreement between Belgium, Luxemburg and the Netherlands - continued to exist alongside the European Economic Community). Typically, however, multi-membership is seen as a problem creating inconsistencies that challenge effective economic integration. Many authors such as Gunning (2001), Yang and Gupta (2005), Mwangi and Kuhlmann (2012) and Chacha (2013) have 
qualitatively argued that these overlapping memberships undermine the effectiveness of African REIs. An example of the argumentation is provided by ECA (2004, p. 41).

The overlap among regional economic communities also adds to the burdens of member states. A country belonging to two or more regional economic communities not only faces multiple financial obligations, but must cope with different meetings, policy decisions, instruments, procedures, and schedules. Customs officials have to deal with different tariff reduction rates, rules of origin, trade documentation, and statistical nomenclatures.

Although all these studies claim that multi-membership may limit the potential of these regional blocs to stimulate intra-regional trade, only Chacha (2013) provides empirical evidence to substantiate this claim. Chacha indicates that a one unit of overlap frequency ratio is associated with a reduction in intra-RTA trade by $0.73 \%$ points. Indeed, differences in the rules of origin (RoO) may undermine the effectiveness of the RTAs by creating inconsistent red tape. Also overlapping and multiple memberships may undercut member states' commitment which is a necessary condition for the success of any RTA.

Likewise, it is equally possible that multi-membership offers benefits to countries. Lyakurwa et al. (1997) argue that overlapping membership in the form of a large group within which there are small sub-groups may lead to progress in the African context. These benefits can consist of economic benefits, of economic spillovers from non-economic (aspects of) treaties and of non-economic benefits from economic treaties. As to the economic benefits of RTAs, Cheng et al $(2009$, p. 45) define overlapping membership as a phenomenon whereby one country is involved in more than one RTA. They refer to overlapping membership as a hub and spokes system with the individual country as the hub and the other countries with which it has an overlapping RTA as the spokes. In the context of increasing bilateralism, the hub country through multi RTA membership reduces the probability of becoming the victim of trade discrimination from the spokes that are non-members of the hub's original RTA. 
Specifically, since preferential trade schemes among the African regional blocs are limited in scope and coverage of products, countries that are engaged in multi-membership may enjoy more preferential or market access than countries in single membership. Consider the following illustration in support of this argument, Liberia shares multi-membership in ECOWAS and MRU. Although, ECOWAS' FTA is progressively eliminating tariff on all goods, it initially offers zero tariff only on traditional handicraft and unprocessed goods while the MRU's FTA extends preferential access to both primary and industrial goods. Liberia would want to maintain membership in both blocs as MRU's FTA is likely to increase bilateral trade between Liberia and say, Cabo Verde (like Liberia member of MRU and ECOWAS) more than bilateral trade between Liberia and Benin (only shares membership with Liberia in ECOWAS).

As to the economic spill-overs from non-economic treaties it is important to note that trade agreements form part of a larger set of international political arrangements that bread trust between nations and therefore spill-over effects between different areas may be significant (see, for example, Rose and Spiegel 2010 on the trade and investment effects of environmental treaties). Non-economic spillover effects may emerge in the area of peace economics (Bergeijk, 2009). Murshed and Mamoon (2010) indicate increasing bilateral trade decreases the tendency of escalation of conflicts among states.

Theoretically, we look at multi-membership as an instrument to minimize economic vulnerability to protectionist measures, to maximize economic spill-overs from other regional diplomatic arrangements that differ with respect to the noneconomic issues that they cover and to maximize non-economic benefits in particular if geographic coverage is important.

De Groot et al (2004) find that differences in formal institutional quality play a key role in determining the nature of trade flows. REIs that achieve homogeneous institutional factors (umbrella REIs) can thus be expected to have a stronger impact on intra-REI-trade than REIs that do not achieve homogeneity (competing REIs). So in analysing the impact of overlapping memberships in ECOWAS and SADC, there are two main issues (see Figure 2). ECOWAS member states belong to two other sub-regional groupings WAEMU and WAMZ. These blocs are recognized as 
appendages of ECOWAS working to achieve ECOWAS' overall objective. Additionally, the other regional groupings are not major regional blocs that can compete with ECOWAS. There is growing rapport between ECOWAS and WAEMU in the design of common programme of action on trade liberalisation. They have agreed on common RoO, custom declaration forms and compensation mechanisms (ECA, 2004; ECA, 2012). Typically multi-membership in the case of ECOWAS is not problematic.

Figure 2: Overlapping Membership in ECOWAS and SADC

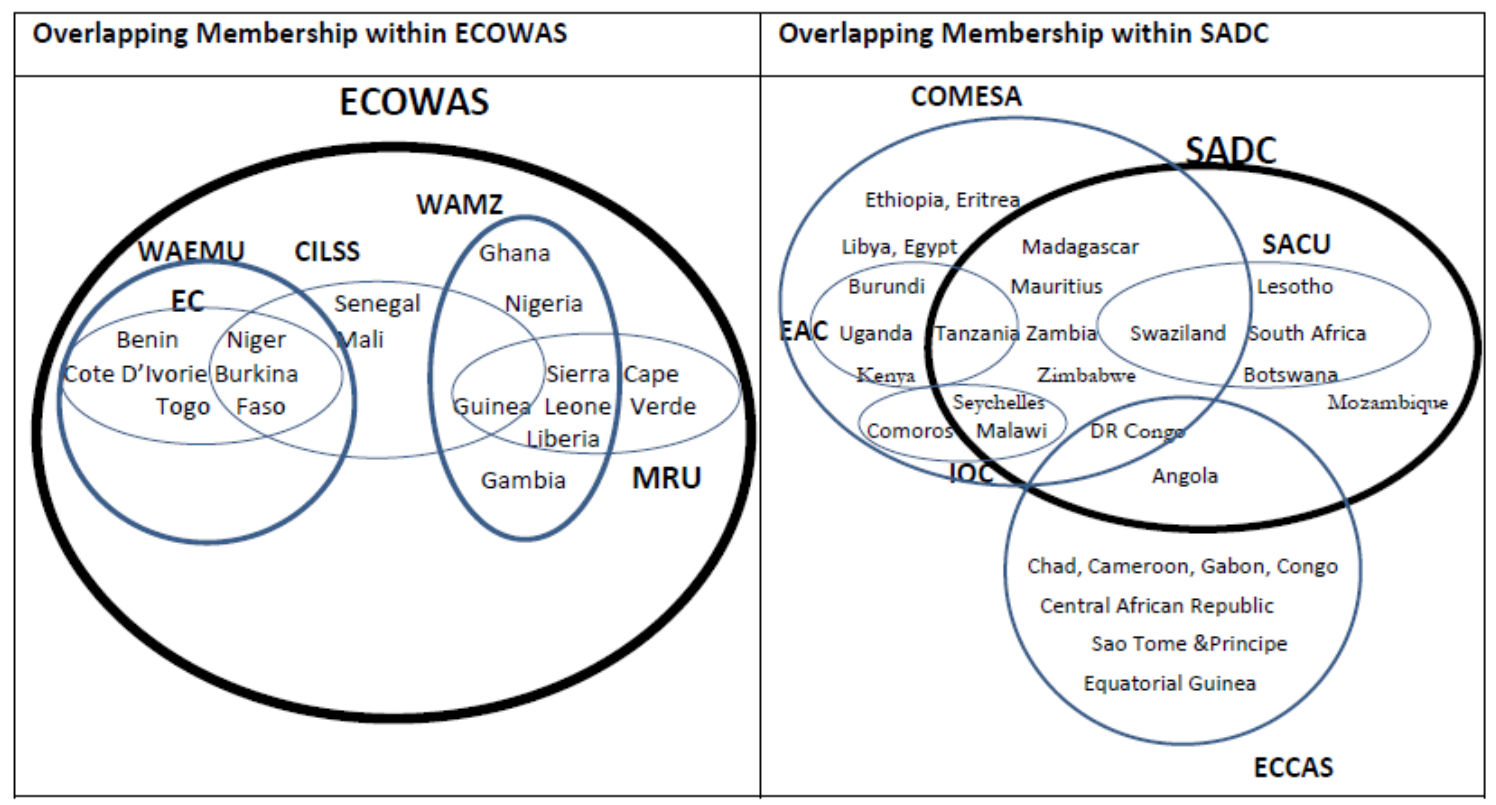

Source: Authors' compuations

This can be contrasted to SADC, whose member states share membership with other important regional blocs such as COMESA, ECCAS and EAC and the majority of the members of these regional blocks are non-SADC members, so that conflicts of interests can occur and major differences in institutions are likely to persist. In support of complication of multi-membership between SADC and COMESA, Brenton and Isik (2012) pinpoint that set of rules of origin governing the trade preferences of two regional blocs are totally different. Therefore, overlapping membership may exert a negative impact or may not increase trade among members significantly. 
In the next sections we will address these issues empirically controlling for other factors in order to distil the marginal impact of multi-membership in ECOWAS and SADC.

\section{Empirical Design and Data}

The design of our econometric investigation is traditional as we use the well-known gravity equation as our main tool (Bergeijk and Brakman, 2010). The gravity model is an applied empirical trade model that describes bilateral trade flows. The key drivers in this model are economic mass and distance. Just as in the Newtonian gravity model this trade model assumes that interaction is weaker if distance is larger and stronger when masses are larger. Thus a large country (area) with substantial production and population will ceteris paribus trade more than a small country. Likewise, countries that are closer to each other trade more than far-away countries. Often the model additionally includes a number of trade resistance factors (such as import tariffs) and trade enhancement factors (such as a common language) that are relevant at the bilateral level. We extend the traditional gravity model as we also include among the explanatory variables a measure for multi-RTA membership. Equation (1) below illustrates the traditional gravity model with Anderson and van Wincoop (2003) introduced multilateral resistance terms (MRT). We use the remoteness index as proxy for MRT just as similarly used in Wei (1996)

$X_{i j}=Y_{i}^{\alpha} Y_{j}^{\beta}\left(\frac{t_{i j}}{\prod_{i} P_{j}}\right)^{1-\sigma}$

$\Pi_{i}$ and $P_{j}$ are the exporter and importer MTR. $t_{i j}$ is the bilateral trade cost between countries.

The set of the countries that we analyse (See Appendix 1) reflects that we want to include all member states of the two major African trading agreements. We study ECOWAS and SADC because we want to analyse groups of countries that are involved in RTAs and where multi-membership is an issue, but where the groups do not show an overlap. ECOWAS and SADC are completely separate clubs that meet this requirement. 
The data for empirical analysis pertain to 1980-2006 because our major source of data for standard variables in gravity model was obtained from CEPII (Centre d'Etudes Prospectives et d'Informations Internationales) which ends at 2006. Before 1980, there is also a copious amount of missing data of bilateral trade flow among the member countries.

\subsection{Models and Estimation}

The dependent variable is total bilateral trade measured in term of exports. $X_{i j t}$ is total annual merchandise exports in million dollars from country $i$ to $j$ at time $t$. The use of exports as measure of bilateral trade takes into account that many importers in Africa deliberately under-report their imports in order to avoid import duties (Baldwin and Taglioni, 2006).

Two models are estimated to measure the impact of multi-membership. The first model focuses specifically on the impact of multi-membership in general. The second model takes the differences in overlapping (multiple) membership within the blocs into consideration as we introduce interactive terms regarding RTA dummies and the multi-membership variable (mult).

$\ln \left(\mathrm{X}_{\mathrm{ijt}}\right)=\alpha_{\mathrm{ij}}+\alpha_{\mathrm{t}}+\beta \ln \mathrm{M}_{\mathrm{it}}+\gamma \operatorname{lnM}_{\mathrm{jt}}+\gamma \mathrm{D}_{\mathrm{ijt}}+\delta$ Multi - membership $_{i j t}+\varepsilon_{\mathrm{ijt}}$

$\ln \left(\mathrm{X}_{\mathrm{ijt}}\right)=\alpha_{\mathrm{ij}}+\alpha_{\mathrm{t}}+\beta \operatorname{lnM}_{\mathrm{it}}+\gamma \operatorname{lnM}_{\mathrm{jt}}+\gamma \mathrm{D}_{\mathrm{ijt}}+\delta_{E}\left(\right.$ Mult $\left._{i j t} * \mathrm{ECOWAS}_{i j t}\right)+\delta_{S}\left(\right.$ Mult $_{i j t} *$ $\left.\mathrm{SADC}_{i j t}\right)+\varepsilon_{\mathrm{ijt}}$

$\alpha_{i j}$ is the dyadic fixed effects, $\alpha_{t}$ are the time dummies and $\varepsilon_{\mathrm{ijt}}$ is error term. $M_{i(j) t}$ is vector of monadic variables of the exporter (importer) in the gravity equation, and they consist of GDP, Population and Area. $D_{i j t}$ is a vector of dyadic variables, consisting of distance between $i$ and $j$, dummy variables capturing contiguity, common language, and common currency. Details on the standard gravity variables are provided in the appendix 2 .

Equation (2) investigates the general impact of overlapping membership and here the null hypothesis in line with the mainstream literature is that its impact is insignificant or negative, because multi-membership creates red 
tape and undermines full implementation of each international agreement. Equation (3) enables us to investigate the impact of multi-membership in the context of ECOWAS and SADC, respectively. The alternative hypothesis is a bit more complex than those tested in the other equations. Since the underlying RTAs appear to be complementing one another in ECOWAS whereas they competing in SADC, we expect a positive impact of multiple memberships in ECOWAS and a negative impact in SADC.

In estimating the gravity model to assess the impact of RTAs on intraregional trade, there are three econometric concerns. First, we may have reverse causality between exports and RTA variables if countries that trade intensively are more likely to form RTAs (Baier and Bergstrand, 2007). The African RTAs were, however, formed at a moment in time when intra-regional trade was still at a very low level. For example, intra-regional trade as a percentage of total trade was only $3 \%$ in 1970. In addition, membership of African RTAs is by and large determined by geographical and political factors. Therefore reverse causality is highly unlikely in our study. Second, we may have unobserved heterogeneity mainly as result of unobserved time-invariant heterogeneity within the cross-sectional units (individual countries) and time-invariant omitted variables such as political, ethic, historical and cultural factors. Ordinary Least squares (OLS) may produce biased and inefficient estimates. Thus, we follow Baier and Bergstrand (2007) method by introducing time effect $\left(\alpha_{t}\right)$ and dyadic $\left(\alpha_{i j}\right)$ fixed effects (FE). Third, the large proportion of zero flows, this stands at $48 \%$ in our dataset. In order to deal with the zero flows we rely on Poisson Pseudo Maximum Likelihood (PPML) estimator, which Santo-Silva and Tenreyro (2006) have shown to be consistent and wellbehaved in presence of large shares of zero flows. The meta-analysis of Afesorgbor (2013) reveals that PPML considerably reduces the upward bias of African RTA effects compare to other methods such as replacing the zero flows with arbitrary small values or using the Tobit estimator.

Thus, in line with these econometric concerns, we used the PPML estimator with the time and dyadic fixed effects to estimate equations (2) and (3). The PPML estimates the gravity model assuming the trade flows are Poisson distributed and thus, an exponential function (equation 4) is used to estimate models. 
$E\left(X_{i j t} \mid Z_{i j t}\right)=\alpha_{i j} \exp \left(Z_{1 j t}^{\prime} \beta\right)$

where $Z_{i j t}$ and $\beta$ are vector of covariates and coefficients respectively.

\subsection{Data}

We use panel data from the IMF Direction of Trade Statistics (DOTS) dataset for exports registered free on board (f.o.b.; the transaction value at the exporter's frontier). The data relate to 15 Western African and 10 Southern African countries. The number of SADC member states is 10 because DOTS aggregates Botswana, Namibia, Swaziland, Lesotho and South Africa. We could not obtain data on Democratic Republic of Congo (SADC) from IMF DoTs. The data on distance, area, shared border, GDP and population were obtained from CEPII. RTA membership was directly collected from the RTA's websites.

The dataset is a panel with potentially 16,200 (25 x $24 \times 27)$ observations consisting of symmetric trade (export) flows between 25 countries for 27 years. However, in our estimation of models, we have 12,833 total observations because of missing data. Table 3 provides descriptive statistics for the variables comparing the averages for the two main RTAs.

Table 3: Descriptive Statistics comparing ECOWAS and SADC

\begin{tabular}{lll}
\hline Mean of Variable & ECOWAS & SADC \\
\hline Export (million US\$) & 10.3293 & 30.3885 \\
& $(51.8889)$ & $(113.6511)$ \\
Distance (km) & 1319.629 & 2162.346 \\
& $(717.4909)$ & $(1031.753)$ \\
population (million) & 13.546 & 12.3739 \\
& $(25.8507)$ & $(10.9356)$ \\
GDP(million US\$) & 5483.603 & 11479.14 \\
& $(11676.27)$ & $(34418.79)$ \\
Area in square km & 348643.3 & 562616.7 \\
& $(422255.8)$ & $(452336.6)$ \\
Contiguity & .2461 & .3141 \\
& $(.4308)$ & $(.4643)$ \\
\hline
\end{tabular}




\begin{tabular}{lll}
\hline Common Currency & .2248 & 0 \\
& $(.4175)$ & $(0)$ \\
Common language & 0.3830 & 0.6058 \\
& $(0.4862)$ & $(0.4888)$ \\
Observations & 5454 & 1748 \\
\hline
\end{tabular}

(standard deviations in parentheses). Common currency is zero for SADC because members that are in Rand Monetary Area are aggregated in the IMF's DOTS dataset.

Source: Authors' computation

\section{Impact of multi-membership}

As shown in Table 4 (model 1; equation 2) the effect of overlapping membership in general is positive, an additional RTA membership increases country-pair bilateral trade by $1.27 \%$. Model 2 finds that the impact of overlapping membership differs considerably between ECOWAS and SADC. Overlapping membership has only a significant positive impact for ECOWAS and insignificant effect for SADC. The interaction terms ECOWAS*Multi_membership and SADC*Multi_membership, capture the impact of overlapping memberships in ECOWAS and SADC, respectively. For ECOWAS, additional RTA membership of country-pair increases bilateral trade by $1.21 \%$, possibly reflecting that the 'underlying' REIs WAEMU and WAMZ are complementary to ECOWAS. In contrast, for SADC, a pair of country belonging to additional REI does not significantly increase bilateral trade between them. The results here are in line with Kimenyi and Kuhlmann's (2012) qualitative analysis provided on overlapping (multi) membership as they concur that the extent of multi-membership in ECOWAS is less complex compared to SADC.

TABLE 4: Empirical Results of Multi-membership

\begin{tabular}{lll}
\hline VARIABLES & Model 1 & Model 2 \\
\hline Log Exporter GDP & $0.553^{* * *}$ & $0.553^{* * *}$ \\
& $(0.138)$ & $(0.139)$ \\
Log Importer GDP & $0.309^{* * *}$ & $0.265^{* *}$ \\
& $(0.110)$ & $(0.121)$ \\
Log Exporter Population & 1.237 & 1.992 \\
& $(1.251)$ & $(1.309)$ \\
Log Importer Population & -1.685 & -0.709 \\
& $(1.714)$ & $(1.855)$ \\
Remoteness (Exporter) & -0.000656 & -0.000697 \\
& $(0.000455)$ & $(0.000455)$ \\
Remoteness (Importer) & $-1.60 \mathrm{e}-05$ & 0.000162 \\
& $(0.00106)$ & $(0.00115)$ \\
\hline
\end{tabular}




\begin{tabular}{lll}
\hline Multi-membership & $\mathbf{1 . 2 7 2 * * *}$ \\
& $(\mathbf{0 . 4 5 2 )}$ & \\
Multi-membership *ECOWAS & $1.212 * * *$ \\
& & $(\mathbf{0 . 4 6 1 )}$ \\
Multi-membership *SADC & $\mathbf{0 . 5 3 6}$ \\
& & $\mathbf{( 0 . 3 3 6 )}$ \\
Observations & 12,833 & 12,833 \\
\hline
\end{tabular}

Robust standard errors in parentheses, ${ }^{* * *} \mathrm{p}<0.01,{ }^{* *} \mathrm{p}<0.05,{ }^{*} \mathrm{p}<0.1$

The dyadic and monadic controlling time-invariant variables are differenced away.

Source: Authors' computation

\section{Conclusions and Policy Implications}

The main policy message is about the institutional design of RTAs. Our analysis clarifies under which conditions African 'spaghetti bowl' RTA formation is ineffective. We contrasted the ECOWAS and SADC approaches to regional integration. The ECOWAS approach provides an umbrella that embraces smaller and lower regional integration initiatives. In this approach overlapping multi-RTA membership does not provide a problem. In contrast in the SADC approach we have a hub and spokes setting of membership in competing RTAs and therefore inconsistencies that hamper the RTA's effectiveness are likely to occur (and indeed according to our estimates this actually happens to be the case).

Essentially, we therefore find a positive impact if an additional membership complements the integration process of the original RTA and this provides a clear lesson for the direction into which RTAs could be broadened and strengthened. Firstly, Africa member states should increase their commitments to the various integration processes as this is the only condition for RTAs to be effective and not being purely ceremonial. For member states to be fully committed to single RTA, the level of economic integration must be deepened: the scope and coverage of preferential schemes should be extended considerably so that members can benefit substantially from being single member of an RTA. Progressively, the various RTAs must develop modalities to coordinate activities such that the overlap and duplicative roles would considerably be reduced. The tripartite FTA launched by SADC, EAC and COMESA may be the ideal solution to overcome the challenges associated with overlapping (multi)-membership and this should be embraced by the other RTAs in order to fasten the process of continental integration. Secondly, 
the finding that multiple memberships could be beneficial if the RTAs complement each other also gives the impetus to African Union's effort in establishing an umbrella FTA in the form of the Continental FTA (CFTA). This CFTA should encompass the other REIs and progressively harmonise and integrate their activities, in a similar fashion as ECOWAS playing an umbrella role for the sub-REIs in Western Africa. The conclusion of the paper is consistent with the AU plan of consolidating the RTAs and eventually merging them into a single African Economic Community. Thus, this AU plan, in our opinion is a step in the right direction.

\section{References}

AFESORGBOR, S.K. (2013). Revisiting the Effectiveness of African Economic Integration. A Meta-Analytic Review and Comparative Estimation Methods, Institut for Økonomi, Aarhus Universitet, Economics Working Papers No. 2013-13.

ANDERSON, J. E., and van WINCOOP, E. (2003). Gravity with gravitas: a solution to the border puzzle. American Economic Review 93 (1): 170-192.

BALASSA, B. and STOUTJESDIJK, A. (1975). Economic Integration among Developing Countries, Journal of common market studies 14 (1): 37-55.

BAIER, S. L. and BERGSTRAND, J.H. (2007). Do Free Trade Agreements Actually Increase Members' International Trade? Journal of International Economics, 71(1). 1, 72-95.

BALDWIN, R. and TAGLIONI, D. (2006). Gravity for Dummies and Dummies for Gravity Equation, NBER Working Paper Series 12516. NBER: Cambridge MA.

BHAGWATI, J. and A. PANAGARIYA (1999), 'Preferential Trading Areas and Multilateralism', in J. Bhagwati, P. Krishna and A. Panagariya (eds.), Trading Blocs Cambridge, MA: MIT Press.

BERGEIJK, P.A.G. van (2009). Economic Diplomacy and the Geography of International Trade, Edward Elgar; Cheltenham and BRAKMAN, S. (2010), 'The Comeback of the Gravity Model' (2010), in: P.A.G. van Bergeijk and S. Brakman (eds.), The Gravity Equation in International Trade, Cambridge University Press, pp. 1-26

BRENTON, P., \& ISIK, G. (2012). De-Fragmenting Africa: Deepening Regional Trade Integration in Goods and Services. The World Bank

CHACHA, M. (2013). Regional Integration and the Challenge of Overlapping Memberships on Trade, Journal of international Relations and Development, Advanced online publication, June 2013

CHENG, H. and WALL, H. (2005). Controlling for Heterogeneity in Gravity Models of Trade and Integration, Federal Reserve Bank of St. Louis Review 87 (1): 49-63.

CHENG, X., WANG, Y. and LUI, Y. (2009). Analysis on the Development and Influence of Overlapping Free Trade agreement/Analyses Sur Le Development Et Les Influences Du Chevauchement Des Accords De Libre Echange, Canadian social science 5(1): 44-52. 
CHUI, M., MURSHED, M. S. and PEARLMAN, J. (2002). North-South Models of Growth and Trade, Journal of Economic Surveys 16 (2): 123-65.

ECA (2004). Assessing Regional Integration in Africa, Economic Commission for Africa, Addis Ababa. (2012). Assessing Regional Integration in Africa V, Towards an African Continental Free Trade Area, Economic Commission for Africa, Addis Ababa.

EZENWE, U. (1983). ECOWAS and the Economic Integration of West Africa. London: C. Hurst and Company.

GROOT, H.L.F., LINDERS, G.-J., P RIETVELD AND U. SUBRAMANIAN (2004). The Institutional Determinants of Bilateral Trade Patterns, Kyklos 57 (1), 103123.

GUNNING, J. (2001). Trade Blocs: Relevant for Africa? Journal of African Economies 10 (3): 311-335.

HERMAN, M., WANDSCHNEIDER, K., WARIN, T., and WUNNAVA, P.V (2011).

Southern African Economic Integration: Evidence from an Augmented Gravity

Model, African Finance Journal, 13 (1): 1 - 13

KIMENYI, M. and KUHLMANN, K (2012). "African Union: Challenges and Prospect for Regional integration in Africa". The Whitehead Journal of Diplomacy and International Relations, 13(2), 7-27.

LYAKURWA, W. M., McKAY, A., NG'ENO, N. and KENNES W. (1997). "Regional Integration in Southern Africa: A Review of Experiences and Issues." In A. Oyejide, I. Elbadawi,and P. Collier (eds.), Regional Integration and Trade Liberalization in Sub-saharan Africa: Framework Issues and Methodological Perspectives. Vol. 1. New York: St. Martin's Press.

MURSHED, M.S. and MAMOON, D. (2010). Not Loving Thy Neighbor as Thyself: Trade, Democracy and Military Expenditure Explanations Underlying IndiaPakistan Rivalry, Journal of Peace Research 47(4): 463-476.

ROSE, A. and SPEIGEL, M. (2010). International environmental arrangements and international commerce. In P.A.G. van Bergeijk and S. Brakman (eds), The Gravity Model in International Trade, New York, USA: Cambridge University Press, 255-277.

SANTOS SILVA, J. and TENREYRO, S. (2006). The log of gravity. The Review of Economics and Statistics, 88 (4), 641-658.

SÖDERBAUM, F. (1996). Handbook of Regional Organizations in Africa. Uppsala: Nordiska Afrikainstitutet.

WEI, S. (1996). Intra-National versus International Trade: How Stubborn are Nations in Global Integration? NBER Working Paper 5531.

YANG, Y. and GUPTA, S. (2005). Regional Trade Arrangements in Africa: Past Performance and the Way Forward, IMF Working Paper, WP/05/36, Washington, DC: IMF. 
Appendix 1: Set of countries used in the empirical gravity model.

\begin{tabular}{lll}
\hline Code & Country & Major RTA \\
\hline $\mathbf{1}$ & Burkina Faso & ECOWAS \\
$\mathbf{2}$ & Côte d'Ivoire & ECOWAS \\
$\mathbf{3}$ & Guinea Bissau & ECOWAS \\
$\mathbf{4}$ & Mali & ECOWAS \\
$\mathbf{5}$ & Niger & ECOWAS \\
$\mathbf{6}$ & Senegal & ECOWAS \\
\hline $\mathbf{7}$ & Togo & ECOWAS \\
$\mathbf{8}$ & Gambia & ECOWAS \\
\hline $\mathbf{9}$ & Ghana & ECOWAS \\
$\mathbf{1 0}$ & Guinea & ECOWAS \\
$\mathbf{1 1}$ & Sierra Leone & ECOWAS \\
$\mathbf{1 2}$ & Nigeria & ECOWAS \\
$\mathbf{1 3}$ & Cabo Verde & ECOWAS \\
\hline $\mathbf{1 4}$ & Liberia & ECOWAS \\
$\mathbf{1 5}$ & Benin & ECOWAS \\
$\mathbf{1 6}$ & Angola & SADC \\
\hline $\mathbf{1 7}$ & Madagascar & SADC \\
\hline $\mathbf{1 8}$ & Malawi & SADC \\
$\mathbf{1 9}$ & Mauritius & SADC \\
$\mathbf{2 0}$ & Mozambique & SADC \\
\hline $\mathbf{2 1}$ & Seychelles & SADC \\
\hline $\mathbf{2 2}$ & South Africa & SADC \\
\hline $\mathbf{2 4}$ & Tanzania & SADC \\
\hline & SAmbia & SADC \\
\hline
\end{tabular}

Appendix 2: Variables and definitions

\begin{tabular}{|l|l|}
\hline Variables & Definitions \\
\hline $\begin{array}{l}\text { Monadic } \\
{\left[M_{i(j) t}\right]}\end{array}$ & \\
\hline$G D P_{i t}$ & exporting country's GDP measured in million US\$ at time $t$. \\
\hline$G D P_{j t}$ & importing country's GDP measured in million US\$ at time $t$. \\
\hline Area $_{i t}$ & exporting country's area measured in square km \\
\hline Area $_{j t}$ & importing country's area measured in square km \\
\hline Pop $_{i t}$ & exporting country's population measured in million at time t. \\
\hline Pop $_{j t}$ & importing country's population measured in million at time t. \\
\hline${\text { Dyadic }\left[D_{i j t}\right]}$ \\
\hline
\end{tabular}




\begin{tabular}{|l|l|}
\hline $\begin{array}{l}\text { Mult- } \\
\text { membership }_{i j t}\end{array}$ & is the count of RTAs both country $i$ and $j$ belong to at time $t$. \\
\hline ECOWAS $_{i j t}$ & $\begin{array}{l}\text { dummy variable with value } 1 \text { if } i \text { and } j \text { belong to the ECOWAS } \\
\text { at time } t, 0 \text { otherwise. }\end{array}$ \\
\hline SADC $i j t$ & $\begin{array}{l}\text { dummy variable with value } 1 \text { if } i \text { and } j \text { belong to the SADC at } \\
\text { time } t, 0 \text { otherwise. }\end{array}$ \\
\hline Contiguity $_{i j t}$ & dummy with value 1 if $i$ and $j$ share a land border, 0 otherwise. \\
\hline $\begin{array}{l}\text { Common } \\
\text { currency }_{i j t}\end{array}$ & $\begin{array}{l}\text { dummy variable with value } 1 \text { if } i \text { and } j \text { use the same currency, } 0 \\
\text { otherwise. }\end{array}$ \\
\hline Distance $_{i j}$ & geographical distance between country $i$ and $j$ in km. \\
\hline
\end{tabular}

Note: These variables are standard gravity model variables. 


\section{Economics Working Papers}

2013-20: Ina Charlotte Jäkel: Import-push or Export-pull?

2013-21: Tor Eriksson, Jay Pan and Xuezheng Qin : The Intergenerational Inequality of Health in China

2013-22: Martin Paldam: How do partly omitted control variables influence the averages used in meta-analysis in economics?

2013-23: Ritwik Banerjee: An Evaluation of the Revenue side as a source of fiscal consolidation in high debt economies

2013-24: Nabanita Datta Gupta, Mona Larsen and Lars Brink Thomsen: Do wage subsidies for disabled workers result in deadweight loss? evidence from the Danish Flexjob scheme

2013-25: Valerie Smeets, Sharon Traiberman and Frederic Warzynski: Offshoring and Patterns of Quality Growth: Evidence from Danish Apparel

2013-26: Torben M. Andersen, Jonas Maibom, Michael Svarer and Allan Sørensen: Do Business Cycles Have Long-Term Impact for Particular Cohorts?

2013-27: Martin Paldam: Simulating publication bias

2013-28: Torben M. Andersen and Allan Sørensen: Product market integration, tax distortions and public sector size

2014-01: Leonie Gerhards and Neele Siemer: Private versus Public Feedback The Incentive Effects of Symbolic Awards

2014-02: $\quad$ Casper Worm Hansen, Peter Sandholt Jensen and Lars Lønstrup: The Fertility Transition in the US: Schooling or Income?

2014-03: $\quad$ Mette Trier Damgaard and Christina Gravert: Now or never! The effect of deadlines on charitable giving: Evidence from a natural field experiment

2014-04: Christina Gravert: Pride and Patronage - The effect of identity on pay-what-you-want prices at a charitable bookstore

2014-05: Julia Nafziger: Packaging of Sin Goods - Commitment or Exploitation?

2014-06: Sylvanus Kwaku Afesorgbor and Peter A.G. van Bergeijk: Measuring multi-membership in economic integration and its trade-impact. A comparative study of ECOWAS and SADC 